\section{Conditions on educational success}

The Soviet Union's Five-Year Plan for 1976-1980 will make increasing demands upon the higher educational system. Vera Rich looks at what new degree regulations being introduced could mean for Soviet science

BY 1980 the Soviet economy will require 9.6 million "specialists" and 11 million persons with higher educational qualifications in order to attain the envisaged levels of economic growth and technological expansion. Hardly surprising, then, that considerable attention is being paid to problems of streamlining and improving the Soviet education system, particularly in the higher echelons; but a review of the method of awarding higher degrees is producing changes which can only be regarded as worrying.

The degrees of Candidate of Science (roughly equivalent to $\mathrm{PhD}$ ) and Doctor of Science are not awarded by the Universities, but the Ministry of Education; Universities and Research Institutes make the necessary recommendations, but the confirmation is by no means automatic. The body which assesses the recommendations and awards degrees is the Higher Qualifications Commission (Vysshaya Attestatsionnaya Kommissiya, VAK) of the Ministry.

On January 1 of this year, however, new regulations came into force, introducing a major reorganisation in both the structure of VAK and its operation which must, inevitably, reflect on the whole structure of Soviet research and the academic establishment. According to Professor V. G. Kirillov-Ugryumov, the Chairman of VAK, in a recent Pravda interview, these changes are not merely of an administrative nature; they also have a qualitative significance. The status and "potentialities" of VAK have been extended. Requirements have been raised regarding the level of qualifications and, consequently, on entry into a scientific career.

In its reorganised form, the administration of VAK will be in the hands of a Plenum, a Presidium and a "College", in whose work leading scientists and specialists will participate. There are to be 34 councils of experts dealing with the principal lines of research, and also some 500 "specialised councils" for assessing degree theses, 150 of these councils being entitled to deal with Doctoral degrees. The Presidium and "College" of VAK have been operating since May 1975, and the first session of the Plenum met last July, but the establishment of the councils is not yet complete, although it is hoped to have them all fully organised by June of this year.

Regarding the "qualitative" changes, the new regulations, says Professor Kirillov-Ugryumov, will demand a higher standard in the theses submitted, and the postulants themselves will also have to meet certain more stringent requirements. The new regulations require that they should "combine a profound professional knowledge with a mastery of Marxist-Leninist theory, and with the convictions of an active builder of communist society".

Courses in political theory and participation in practical "community activity" have always formed a de facto compulsory part of Soviet higher education, but the student body and even the staff have tended to regard them as a necessary chore demanding little more than their physical presence. Hitherto the Soviet educational system. although Party-orientated, has permitted a certain number of non-Party scientists to rise to considerable academic heights (Academician Sakharov being the most notable example). The new stress on the political outlook for higher degree postulants, in which their "community and political activity" as well as their scientific knowledge is taken into consideration, and the presence of Party and trade-union representatives on the "specialised councils", suggest that these days may be over, and that the non-Party element in science will gradually be phased out.

Significant, too, is the fact that almost all Professor Kirillov-Ugryumov's comments on the "distinguishing features" of the new regulations deal with these political aspects; on the academic side he notes merely that all exemptions from the examinations for the degree of Candidate and other "weaknesses" of the existing system will be eliminated, and that a higher standard will be demanded from the "official opponents" in the formal defence of doctoral theses.

Although the new regulations had not been published at the time of their introduction (a booklet of the full text is promised), their content and implications were well-known in Soviet academic circles some months in advance. As early as August 1975, reports from dissident sources were affirming that, under the new system, from 1985 onwards no non-Party member would be able to hold a major academic or scientific post, so that students wishing for a successful career in science would be well-advised to take steps to enter the Party ranks (via the Komsomols) at their earliest opportunity.

Politically speaking, the new emphasis on partiinost' does make a certain amount of sense--it was precisely the participation by the non-Party scientists that gave the dissident movement its real strength and significance. Scientifically speaking, however,. while the new regulations may, in Professor Kirillov-Ugryumov's words, reflect a "qualitative" change, historical parallels would suggest that it is one which, in the long run, could be detrimental to Soviet science as a whole.

\title{
Trieste still troubled
}

Gillian Boucher reports from Trieste on the threat facing an international institution supported by funds from diverse sources

THE International Centre for Theoretical Physics at Trieste is threatened with a serious cut in funds which, if not compensated by money from other sources, could result in its closure.
What is in jeopardy is the contribution from the United Nations Development Programme (UNDP), which was to have provided nearly one-fifth of the 1976 budget of $\$ 1.2$ million. UNDP provides funds for specific scientific activities: the regular programmes on solid state physics and applied mathematics. Since an irreducible $35 \%$ of the total budget goes on overheads, cutting out UNDP support would mean an enormous reduction in the scientific work of the centre.

Disaster almost struck just before Christmas when the centre received a cable from UNDP announcing that no money would be available for the course (then due to start in three weeks' time) on the interaction of radiation with condensed matter, and that the sum for the 1976 mathematics course would be halved. Fortunately the centre had in writing UNDP's previous promise to support these courses, and managed to persuade UNDP that it was impossible to cancel the solid state course. Funding for the course was 
restored 17 days before it began, but the cuts for next autumn's mathematics course remain.

More serious is the likelihood that UNDP funds will soon dry up altogether. UNDP has been suffering badly from inflation and from the failure of some countries, notably the USA, to pay up. Its projected shortfall for 1976 of $\$ 100$ million means cutting back on many projects, and Trieste is a likely victim. Trieste is also likely to be hurt by the growing proportion of UNDP funds being assigned to individual nations rather than international projects.

The centre has always found living with UNDP a precarious business: meetings and courses have to be planned two years ahead while UNDP commits itself for only a year at a time. The Swedish International Development Authority, which provides the bulk of the funds to support the centre's Associates (scientists from less developed countries who come to do research at the centre three times in five years for up to three months at a time), also votes funds annually. More stable are funds from the Italian government (currently providing $\$ 350,000$ a year) and the International Atomic Energy Agency (IAEA) ( $\$ 225,000$ a year), which votes funds on a two-yearly basis. To ease planning headaches and reduce the "rampant feeling of uncertainty" among the centre's small technical staff, an ad hoc consultative committee did in fact report to IAEA last summer that the unstable UNDP contribution should be taken over by the centre's stable sources of income.

With luck that is what will now happen. IAEA and UNESCO have recently expressed a wish to compen- sate the centre if UNDP funds dry up, and are proposing to increase their funding to $\$ 450,000$ and $\$ 300,000$ respectively. Two potential problems seem to have been overcome. The first was that the IAEA contribution has been no greater than that of UNESCO since 1970, the year in which UNESCO first became a major source of funds. IAEA has however now agreed that its contribution need not be fixed at the UNESCO level, and indeed that with UNESCO's current impoverishment such a rule would be absurd. The other difficulty was that UNESCO's policy has been to fund a project for no more than 10 years, after which other sources of income (primarily national governments) are supposed to have been found. But there is now hope that the rule will change, as the committee studying it recently reported to UNESCO that it is outdated, a relic of the era of centres set up by regional bodies. Certainly it would be shortsighted in the extreme to apply the rule to a centre used by over 50 nations, most of them poor.

There should thus be no fundamental difficulty. The centre's well-being will depend upon the attitudes of those attending the imminent executive board meetings of IAEA and UNESCO and their general conferences in September and November of this year. At Trieste there are worries particularly about Britain's representative at UNESCO, Sir Harold Thompson, who is likely to repeat his view that Trieste is eating up too large a slice of UNESCO's \$1 million basic science cake. and may sway some of the Commonwealth countries. Ironically, at the same time that British scientists have provided the strongest support for Trieste and the backbone of its teach- ing, the British government, through the international agencies, has caused it great worries.

If the proposed increases are approved by IAEA and UNESCO the centre will be slightly better off than at present but will of course have to exist at this level of funding through the next four years' inflation. Next year is in any case bound to be a messy one because the present uncertainties about money make planning almost impossible. But this year's programme is the largest ever and it is hoped at least to maintain the present level of activity: three 3-month courses and around 1,000 scientists passing through each year. New ideas are being tried; this summer there is a science teaching programme designed in particular for those scientists whose backgrounds are so weak that they cannot benefit from the other activities of the centre. The emphasis of the centre is on science at all cost; two of the three senior administrators as well as several secretaries have recently been made redundant, with the inevitable result of reduced efficiency and some discontent among the remaining staff.

If the UNDP funds are not replaced by those from IAEA and UNESCO, the centre's director Abdus Salem would prefer it to close rather than to continue with a grotesquely reduced programme. Closure would be a tragedy. The centre educates, stimulates and boosts the morale of thousands of physicists from less developed countries. providing them with the sort of contact with their peers which any American or European scientist takes for granted. And it is really very cheap: its running costs are the equivalent of less than $1 \%$ of Britain's SRC budget.

\section{China energy link weakens}

JAPAN's energy policy still accords an essential role to oil, even though the crisis precipitated in 1973 showed it to be the most vulnerable of the industrialised countries because of its great dependence on oil imports. Like those countries, however, Japan is now having to cope with an emerging glut of oil, and in the last couple of months relations with one comparatively new supplier in particular appear to have changed.

The supplier is the People's Republic of China, with which the level of Japan's two-way trade last year reached a record $\$ 3,800$ millions. The two countries began their oil trade in 1973, and last year oil produced almost half of China's export earnings from Japan.

In January there were reports, viewed at the time rather sceptically by Japan's refiners and electricity companies, that China might buy over $60 \%$ more steel from Japan in return for Japan increasing its purchases of Chinese oil from 8 million tonnes last year to 10 million in 1976.

The following month, however, before any 1976 agreement was concluded, China advised Japan that its February shipment would be halved. The same was expected for March as well, and one theory had it that supplies were being diverted to North Korea. When the first contracts were finally agreed in early March, the trend was confirmed: one of Japan's two major importing consortia agreed a $12 \frac{1}{2} \%$ cut. The other principal buyer has since contracted to take a
$30 \%$ reduction. Japan's total imports of Chinese oil are thus unlikely to exceed 6.1 million tonnes, although there are options which, if exercised, would boost the total to 1975 levels.

It now appears that the February reductions merely anticipated the smaller contracts, and that the reductions themselves simply reflect Japan's oil needs at the present time (with the fact that China's oil is more expensive and less easily processed also playing a part). China may still be hoping to cash in on any upturn in Japanese demand, and might then be looking to offer longer-term oil contracts in return for the Japanese steel it now seems to want and which Japan's steel companies (shareholders in the oil importing consortia) are keen to sell. For the moment it is China's political upheavals which may preclude immediate progress on this. 